\title{
Creating a tourism destination through sustainable development: case study coastal area of Abuqir, Alexandria, Egypt
}

\author{
A. El Menshawy ${ }^{1}$, S. Sharaf Eldin ${ }^{2} \&$ F. Fekry ${ }^{2}$ \\ ${ }^{1}$ Architecture Department, Arab Academy for Science Technology and \\ Maritime Transport, Alexandria, Egypt \\ ${ }^{2}$ Architecture Department, Pharos University, Alexandria, Egypt
}

\begin{abstract}
The increasing attractiveness of the tourism industry leads new destinations to emerge and established destinations to maximize their efforts in order to defend and increase their competitive positions. Besides, high level of vulnerability because of the economic crisis, regional conflicts, natural disasters etc. increases the competition among the destinations also in the same regions.

Alexandria has grown rapidly in recent decades, in proportion to the growth in population and population density, as well as to the urban and industrial development. Modern Alexandria stretches over a narrow and irregular strip of land between the Mediterranean Sea to the north, Lake Mariout (a major coastal lagoon) to the south and Abuqir Bay to the east. Abuqir Bay region in the southern part of the Mediterranean is well known promising tourist, industrial and agricultural site that needs to be developed in order to compete in the touristic map of Alexandria. The coastal zone hosts important architecture features, ecological habitats, economic centres and archaeological sites. However, development in the region has been limited. This region with its different but unique culture, natural beauties and attractiveness can gain more from the international tourist movements.

The main objective of this study is to work out a plan for strategic development of region through establishing the tourism industry, the creation of a touristic path and marketing the tourism products. Identifying and assessing problems and changes of the region will be a part of the study. Sustainable development of the region and the creation of a network connection between different fortresses in Abuqir will be the cornerstone in increasing the
\end{abstract}


competitiveness of the region as touristic destination. The methodology could be replicated with other similar regions suffering from the same limitations.

Keywords: Abuqir, sustainable tourism, defensive architecture, fortresses, culture tourism.

\section{Introduction}

Tourism is one of the largest and fastest growing industries in the world. It is an increasingly important source of income, employment and wealth in many countries. In the Mediterranean, tourism is viewed as one of the most important industries representing nearly 30 percent of the world's international tourist arrivals and receipts from tourism.

Architecture and tourism are connected together as tourism sells beautiful experiences and places and architecture makes an essential contribution to design successful tourism destinations. Culture promotes the mutual understanding between human beings of all classes and nurtures the fundamental values of modern society.

The sustainability of tourism would then suggest preserving the valuable communities' assets - the historical sites and buildings, traditions, culture, heritage, attractions and natural beauty - for future generations and for long-term economic and social gain. The economic value in the protection of such assets helps both small and large communities enhance the overall tourism potential. Recent studies have demonstrated that an increasing number of travellers are interested in seeing and doing more and are willing to stay longer and spend more money in areas that sustain the culture and environment (Steel [1]).

The Plan of Implementation adopted at the World Summit on Sustainable Development (WSSD), held in Johannesburg (South Africa) from 26 August to 4 September 2002, identified further measures to promote sustainable tourism development, with a view to increasing "the benefits from tourism resources for the population in host communities while maintaining the cultural and environmental integrity of the host communities and enhancing the protection of ecologically sensitive areas and natural heritages" (UNEP [2]).

Tourism is a crucial factor in Egypt's economic recovery being the foreign exchange source and representing one in every seven jobs. Yet in spite of all efforts, Egypt's share in international tourism remains limited and significantly smaller than its potential.

Alexandria, with a population of 4.1 million, is the second-largest city in Egypt, and is the country's largest seaport, serving approximately $80 \%$ of Egypt's imports and exports. Alexandria is also an important tourist resort. Alexandria City has a unique character from the historical and tourist points of view. Alexandria remains the main local tourism destination, but receives only three percent of Egypt's international visitors each year (Eiweida [3]).

New approaches to sustainable tourism development in Alexandria should not only seek to minimize local environmental impact, but also give greater priority to community participation in creating new tourism destination and poverty reduction in finding jobs in those promising areas. 
This paper will present the linkage between cultural tourism and economic development in Alexandria and will emphasizes the cultural sustainability as the guarantee for achieving cultural tourism assets.

\section{Cultural tourism and sustainability}

Stefano Bianca in his paper entitled "Urban Conservation in the Islamic World" mentioned that most of the places of historic interest are located in the old parts of the cities and towns which have a physical and social character that singles them out from the rest of the city.

But such areas are in a continual flux of change, readjusting to the changing demands of economy and related activities. With or without government intervention changes in uses, rebuilding and renovation are taking place. This is both encouraging and unfortunate. These actions are changing the basic character of historical areas.

Buildings of significant cultural importance are being destroyed and communities and activities that lend character to the areas are being disrupted. Monuments which lose their original function are often considered useless and unnecessary. They become derelict, misused or even left to the mercy of general public. Monuments in remote areas are usually not taken care of (Daifuku [4]).

The economic perspective of cultural tourism can be defined as the way by which the cultural significant community can do economic development achievements by marketing its cultural potentials. Actually it acts in two compatible ways, the first draws the linkage between cultural tourism and economic development, and the second emphasizes the cultural sustainability as the guarantee for achieving cultural tourism assets within the ecodevelopment understandings.

Sustainability as a conceptual understanding constitutes the framework within which cultural could be addressed. However, it is important to sustain the cultural features that shape the supporting initials for any sustainable cultural tourism industry. The dynamic typology of cultural sustainability understandings draws a methodology for treating our inherited cultural over layers as a living organism. It could be developed, upgraded and reinvented to create a new interactive adapted image of that original one (Al-Hagla [5]).

\section{Case study: Abuqir region}

The last two centuries has brought to Alexandria most of its current urban characteristics. It is now seen as a city of a longitudinal spread building mass compared to its width. Its expansion overland is physically restricted by a number of physical constraints. Both the Mediterranean to the north, the Lake Mariut to the south and Abuqir Bay to the east, working as natural guidance to Alexandria's development axes.

The relation between Alexandria and Abuqir is an old and special relation due to its historical roots. Scientist had an argument about the origin of Abukir district, is it Canope or Menouthis City which lay two miles east Abukir, others 


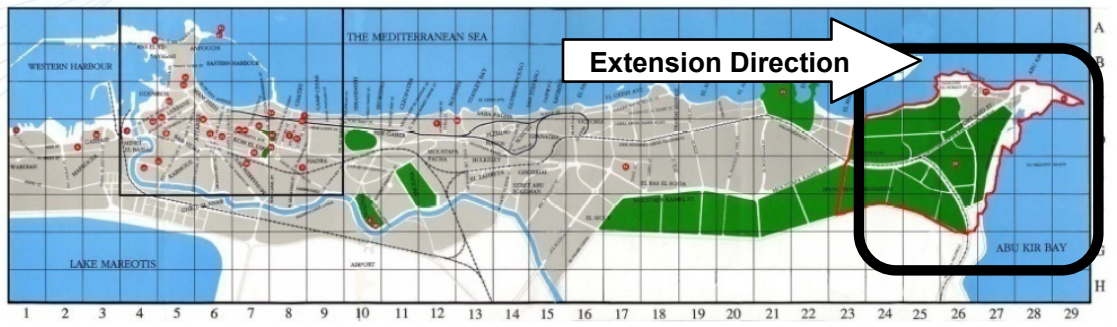

Figure 1: Alexandria linear extension direction towards Abuqir. (Source of the map: Awad Enterprises and researcher modifications (Awad [6])).

say it is named after the Christian saint Abukir who fought for the Christianity in its first ages and was killed and buried in this land so it has been known by his name since the 3rd century (Wikipedia [7]).

Since the birth of Alexandria in the 4th century B.C Canope changed from being a separate city to a district in Alexandria.

In the Ptolemaic and roman eras the recreational role of Canope started and it became famous with its recreational activities so it was the preferred place for the Alexandrians to have fun and leisure.

From the religious view, Canope was very famous due to the presence of the large Temple of Serapis which was constructed by Ptolemy the third.

In spite of the dryness of the Canopyan branch of the Nile in the 9th century A.D, and losing Canope a lot of its trading importance, her special geographical site kept her as an important and premier military point in Alexandria.

This point which led to the founding of a lot of military buildings and forts especially in the Mamluk, Jarks and Mohamed Ali eras.

And as a result of all what mentioned on different activities among Abukir different ages this erected its special and the variety of its pattern and land use (Goddio [8]).

\subsection{Place assets: values and qualities that make the area worthy to be preserved and revitalized (Orbasli [11])}

\subsubsection{Age and rarity value}

The presence of old monuments from different eras and the older their structures are, the more value is likely to be attached to them.

\subsubsection{Architectural and artistic value}

The exemplary qualities of design and proportion and the contribution that the architecture of main monuments in Abuqir has made to the quality of the everyday experience is their architectural value. 


\subsubsection{Associative value}

The association that a building or place has with an event or personality in history is its associative value. Abuqir Bay is the place where on 1 August 1798, Horatio Nelson fought the Battle of the Nile, often referred to as the "Battle of Aboukir Bay" (Gallo [12]).

\subsubsection{Cultural and value}

Fortresses are a special touristic attraction points as they represent one of the rare military architectural style present in the Mediterranean cities. Along the entire Egyptian coastline, the Bay of Aboukir certainly promises the most spectacular archaeological discoveries. Its vast extent and relatively little depth must indeed contain a number of monuments and vestiges of which any discoveries made so far can only produce a vague idea. Also in 1992, the European Institute of Underwater Archaeology IEASM research teams have uncovered exceptional works from Alexandria and the sunken cities of Canopus and Heracleion in the Bay of Aboukir. Statues of ancient Egyptian gods, sphinxes, ritual instruments, and gleaming golden vessels have been pulled up from underwater (Goddio [8]).

\subsubsection{Educational and historical value}

History embodied within the building fabric is the evidence to events and life in the past. In addition, the distinguished architectural features and shape grammar of the fortifications are good examples of the Mamluk and Mohamed Ali eras which can be studied.

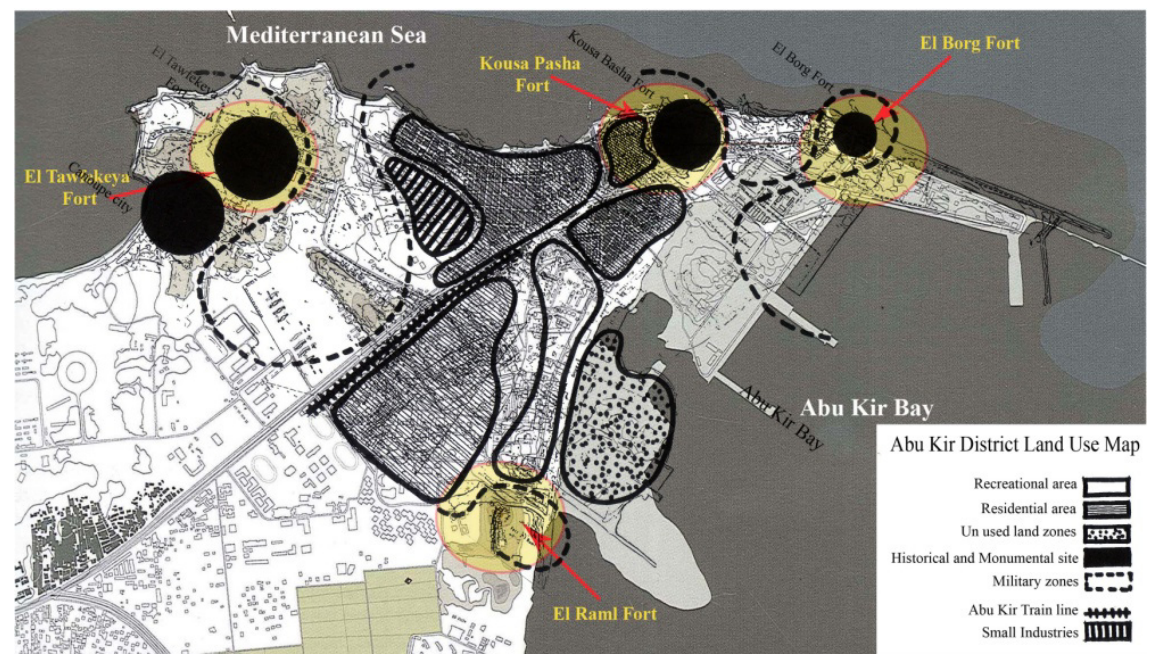

Figure 2: $\quad$ Abuqir land use map. (Source of the map: researcher, Ferro [9] and Azam [10].) 


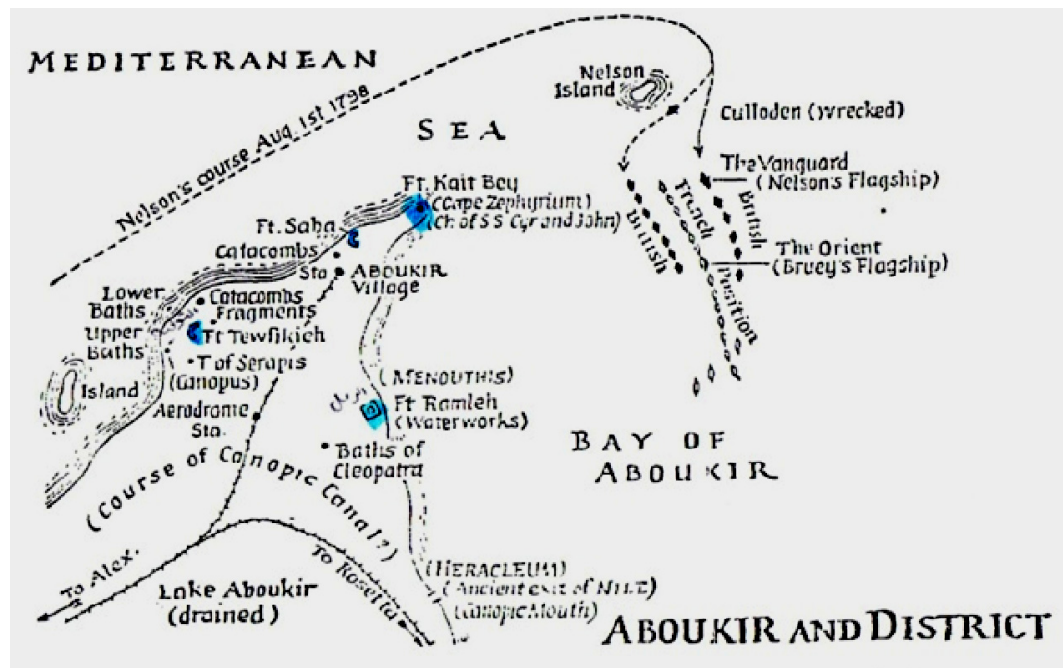

Figure 3: Abuqir old features. (Source of the map: Morcos [13].)

\subsubsection{Local distinctiveness}

Historical architecture assets are often valued for their distinctive characteristics in the face of repetitive and similar international styles of architecture.

\subsubsection{Political and public value}

Abukir's historical roots and its being a strong axe of development, enhance its political potential. Creating culture touristic destination can yield economic development at the local, regional, and national levels, creating jobs and bringing in much-needed foreign income.

\subsubsection{Townscape value}

Historical sites in Abuqir contribute to create value of townscape. The variety of constituents of all settings creates a very dynamic pattern that draws the perspective of the area's identity. Moreover, the physical space proportion creates movement corridors that support vitality of the city parts. Also being a coastal part enhances the touristic potential and emphasizes its uniqueness.

\subsection{Abukir defensive architectural assets}

The Abukir site is unique as it represents an expression of the local community's culture and it also obtains many unique Mediterranean architectural attributes and features such as defensive architecture. By revising the local city guides it was noticed that many sites of architectural and historical importance are not listed in Abukir area. Through actual visits to these sites, it is clear that they face severe threats due to neglect and deterioration. 
Table 1: $\quad$ SWOT analysis of Abuqir area.

\begin{tabular}{|c|c|}
\hline Weaknesses & Strengths \\
\hline $\begin{array}{l}\text { - Need to increase staying visitors } \\
\text { - Available accessible touristic } \\
\text { points are not attractive enough } \\
\text { - Currently limited linkages to area- } \\
\text { specific cultural attractions to } \\
\text { create a long-stay incentive (e.g. } \\
\text { forts are in military areas) } \\
\text { - lack of cultural tours in the area, } \\
\text { - Low quality water resources due to } \\
\text { excessive pollution and soil } \\
\text { salinization which led to } \\
\text { continuous deterioration of land } \\
\text { productivity in the region.(El-Raey } \\
\text { [14]) } \\
\text { - In addition, lack of infra-structure, } \\
\text { shortage of institutional capabilities } \\
\text { and } \\
\text { - Low awareness constitutes strong } \\
\text { obstacles against development in } \\
\text { the region. } \\
\text { - Streets are predominately ruled by } \\
\text { cars leaving the pedestrian urban as } \\
\text { a secondary space. } \\
\text { - Lack of dialogue between the old } \\
\text { ruins sites and new buildings in the } \\
\text { same area. } \\
\text { - New buildings have little relation } \\
\text { to the ground plane, and create a } \\
\text { monotonous block edge for } \\
\text { pedestrian. } \\
\text { areas in the district. } \\
\text { and mass transportation. } \\
\text { - }\end{array}$ & $\begin{array}{l}\text { - Bay region in the southern part of } \\
\text { the Mediterranean is a highly } \\
\text { diversified accessible area. } \\
\text { - It is well known promising tourist, } \\
\text { industrial and agricultural site. The } \\
\text { coastal zone hosts important } \\
\text { ecological habitats, economic } \\
\text { centers and agricultural resources. } \\
\text { - Leader in the area in terms of } \\
\text { tourism assets (submerged } \\
\text { monuments, archeological sites, } \\
\text { Nelson Island, forest at the Dead } \\
\text { Sea and Paradise Bay). } \\
\text { - Its geographical position made her } \\
\text { accessible for many visitors } \\
\text { annually. } \\
\text { - Contains rare defensive } \\
\text { architecture of distinguishable } \\
\text { values. } \\
\text { - Leader in terms of diversification } \\
\text { and desire to diversify further (i.e. } \\
\text { rare Mediterranean defensive } \\
\text { architecture, battle field scenes, } \\
\text { sunken treasures, etc.). } \\
\text { - Farketing muscle } \\
\text { between Mediterranean basin } \\
\text { fortresses. } \\
\text { to the resetta branch of the River } \\
\text { important sanction to migrating } \\
\text { birds and aquaculture. }\end{array}$ \\
\hline
\end{tabular}


Table 1: $\quad$ Continued.

\begin{tabular}{|c|c|}
\hline Threats & Opportunities \\
\hline $\begin{array}{l}\text { - Abuqir is losing its identity by } \\
\text { going 'all over the place. } \\
\text { - Very traditional old fashioned } \\
\text { structure of tourism industry with } \\
\text { little emphasis on touristic assets. } \\
\text { - Danger that existing allies could be } \\
\text { alienated. } \\
\text { - The forts are not all listed and } \\
\text { eventually threatened to demolish. } \\
\text { - Underground water and sanitary } \\
\text { problems on building structures and } \\
\text { sunken treasures. } \\
\text { pontamination of freshwater from } \\
\text { pollution by untreated sewage. } \\
\text { ocean tourism activities, such as } \\
\text { snorkeling, scuba diving and sport } \\
\text { fishing, can threaten fisheries and } \\
\text { other marine resources. } \\
\text { - In addition, tourism in many } \\
\text { destinations could be particularly } \\
\text { threatened by external } \\
\text { environmental shocks, notably the } \\
\text { potential threat of global warming } \\
\text { and sea-level rise. }\end{array}$ & $\begin{array}{l}\text { - High tourism potential and its } \\
\text { effect on Egypt economy. } \\
\text { - Overseas customers, the numbers } \\
\text { of which are increasing, demand } \\
\text { Culture Heritage and products } \\
\text { - Increasing tourist numbers } \\
\text { - Increase of interest to the cultural } \\
\text { tourism in world scale } \\
\text { - Income of tourism will enhance the } \\
\text { area infrastructure and utilities } \\
\text { development. } \\
\text { - Opportunities to be linked with } \\
\text { other Mediterranean defensive } \\
\text { architecture. } \\
\text { - Resource for inter-Mediterranean } \\
\text { culture exchange through network } \\
\text { with similar defensive architecture. } \\
\text { - Interest in development of } \\
\text { innovative products and creation of } \\
\text { linkages through different touristic } \\
\text { points. } \\
\text { - Methods and ways of marketing a } \\
\text { tourist site, both internally and } \\
\text { externally. } \\
\text { - Existence of the Ministry of } \\
\text { Tourism and Environment. } \\
\text { Existence of touristic agents. }\end{array}$ \\
\hline
\end{tabular}

As the Mediterranean was always a place of tensions and conflicts. Fortifications and defensive buildings represented an integral component of the planning scheme of Mediterranean cities during the $18^{\text {th }}$ and 19th centuries Abuqir, main part of Alexandria located on the Mediterranean, was always prone to attacks and invasions from the outsiders. Studying defensive architecture is important because:

- It represents part of Mediterranean traditional architecture.

- It was built by craftsmen with local materials and expertise.

- It is an expression of the local community's culture.

Defensive architecture in Alexandria is comprised of walls, towers and forts. The construction of defensive buildings in Alexandria was active during the reign of 
Mohamed Ali, 1805-1849, for the protection of his realm against invaders. The assigned person for implementation was the French engineer Galise Bek who constructed around 16 forts in Alexandria during the 1840's .the number increased later to 25 forts at the end of Mohamed Ali's reign. Moreover he established an administrative authority responsible for defensive buildings and forts that was called "Maslahat al Istehkamat" or Department of Fortification (Yasser [15]).

\section{Proposed project to be implemented in Abukir region}

Create the path of tourism in Abuqir, includes the valorization, tourist development and economic use of fortifications on conservation principles and management task of the complex order. These include the so-called military ring roads that can connect the individual fortifications with each other. There are four well known fortresses in Abuqir: El-Tawfikia Fort, Kusa-Pasha Fort, El Borg fort and El Raml fort.

According to Doxiades, three main forces shape any new dynamic urban system (Sap [16]).

- Conceptual forces of existing settlements.

- Linear forces of modern transportation systems.

- Aesthetic forces of attractive locations which are the fortifications in our case.
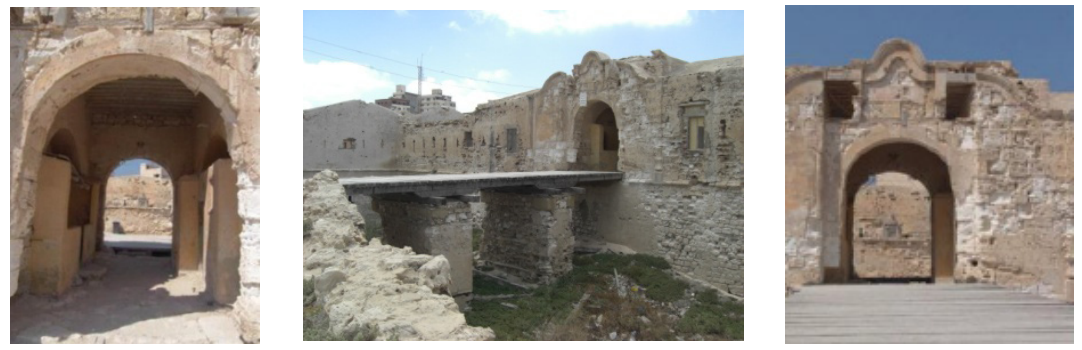

Figure 4: Photos of the fortifications. (Source: the researcher.)

The topical property of an "architectural monument" and, in this case, the special group of "fortresses" even more so, not only needs special technical competence in approach but, moreover, a high degree of creativity in development, information providing and public relations. Nonetheless, many positive examples show that precisely the topic of "fortresses" or in an extended sense "military history" offers a perfect platform for making use of the increasing interest in the historical aspects of regions and corresponds to an increased desire for identification and local orientation. Based on a broad focus of cultural specimen coding, fortresses should not only be thematically developed individually but also appear particularly suited to being included in 


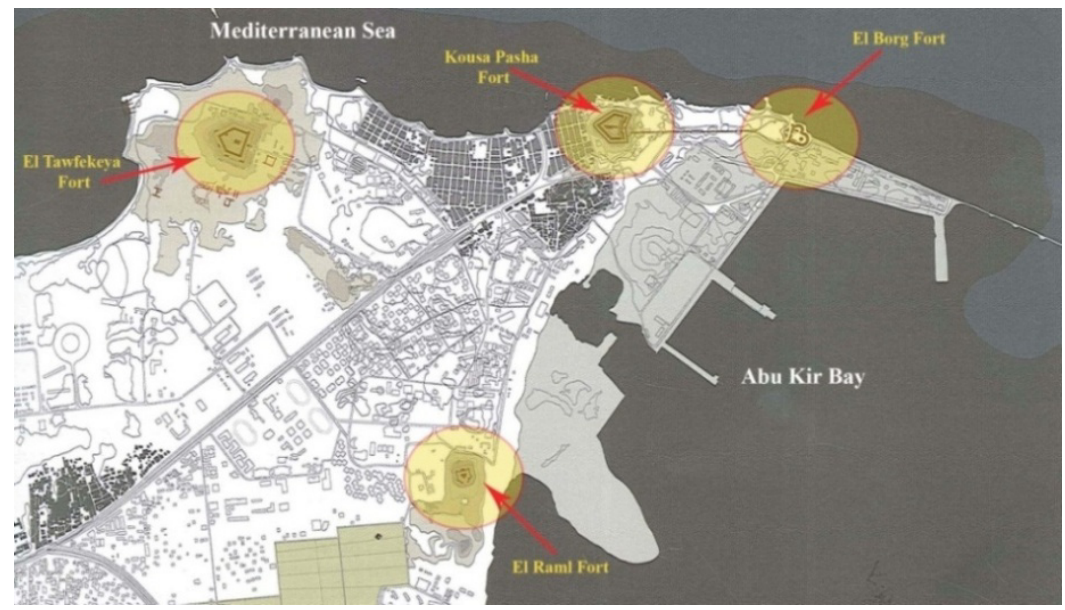

Figure 5: Fortifications map in Abuqir. (Source: Ferro [9].)

integrated cultural landscape development concepts, marketing approaches and identity plans. The concepts of new forms of utilization of fortresses (tourism, cultural site, historic exhibit, and entertainment site respectively) are nowadays a criterion to what extent a city or region can create impulses for its own development. Development also must include not only traffic connections but also the provision of "utilities" in the area.

Illustration of the historical battles that took place in Abuqir Bay such as the "Battle of the Nile" between the British and French army can create an attractive tourist asset.

In addition, a visit to the sunken area of Abuqir Bay and Nelson Island, underwater diving expeditions and watching the underwater archaeology can be another source of attraction.

Optimum utilization of the elements of the region's location is a privileged for the establishment of a global touristic destination who seeks to increase the attractions of the city of Alexandria. Activating the program of tourism development for the region and the involvement of the local people in management and implementation the project, will reduce poverty and unemployment among the population of the region.

The potential relationships between tourism, conservation, and planning within the sustainability discourse in Abukir area can be summarized as follow four objectives (1) the need for long-term active planning, (2) the need to protect the cultural heritage as a natural resource that if neglected will be degraded, (3) the acceptance of rapid change of the urban fabric and development to ensure continuity, and (4) the need to reconsider equitable access to heritage resources by the local community and visitors. 


\section{Conclusions}

The development of the area is one of the best economic projects that can achieve sustainability and economic benefits and can cover the entire project expenses and running costs in addition to achieving rewarding profits.

One of the major intentions of the study is to highlight historical areas or neglected sites such as fortifications that have the scalability and classified according to the priority to be converted to tourist destinations and determine the appropriate concepts of development through the identification of potentials available in the region. Raising awareness among local residents, protecting these sites from further deterioration, and finally promoting these sites for cultural tourism are also main targets in achieving sustainability in culture tourism. Creating a planned ring road will embrace the defensive architecture in the site and will connect it with other touristic assets. It is expected that the intervention will be the driving force for social and economic development and an efficient tool for culture tourism and inter-Mediterranean cultural exchange.

Creating touristic destination in Abukir could operate to improve local incomes, saving and enhancing whole areas. Second, tourism also has the potential to create more demand for conserving neglected valuable fortifications and overlooked traditional environments. Third; tourism can create uses for redundant historical buildings, which if carefully managed, can contribute to their development. Fourth, tourism can also increase an appreciation for the historic environment, contributing to greater local and cross-cultural understanding.

In conclusion, tourism can have positive attributes for conservation and development in heritage places. The principal goal for sustainable planning is to create a strategy for minimizing the adverse impacts and maximizing gains from tourism. This would have to include the management of the cultural resources and the quality of new development, the uses and activities the built environment sustains, and the integration of both these factors with the socio-cultural and socio-economic needs of the local community. The paper finally emphasize both, the continuity of values and the articulation of the physical setting of Alexandria's historical Abukir area so as to guarantee that the preconditions for the cultural tourism assets are preserved and passed on from generation to another. Integration and diversity of cultural assets to create a cultural heritage accessible and usable for all is the key to create touristic destination. The methodology could be replicated with other similar regions in the Mediterranean basin suffering from the same limitations.

\section{References}

[1] Steel, J., Sustainable Architecture, Principles, Paradigms, and Case Studies, McGraw- Hill: New York, 1997.

[2] UNEP, Québec Declaration on Ecotourism, agreed at the World Ecotourism Summit 2002, Online. http://www.uneptie.org/pc /tourism/ecotourism/wes.htm 
[3] Eiweida, A., Alexandria City Development Strategy for Sustainable Development; Villes en development, Bulletin de la coopération française pour le développement urbain, l'habitat et l'aménagement spatial, $\mathrm{N}^{\circ} 75$, March., 2004.

[4] Daifuku, H., The Problems of Conservation in Developing Countries and the Role of International Organizations. In Adaptive Reuse: Integrating Traditional Areas into the Modern Urban Fabric, Margaret Bentley Sevcenko, (ed). Cambridge, Mass, MIT Laboratory of Architecture and Planning, 1983.

[5] Al-Hagla, K.S., Cultural Sustainability: An Asset of Cultural tourism Industry; Dipartimento di Economia "S. Cognetti de Martiis"; International Centre for Research on the Economics of Culture, Institutions, and Creativity (EBLA), working paper No.06/2005.

[6] Awad, M.; Personal communication, Tourist Map introduced by "AWAD enterprise" representing all historical sites in Alexandria, Alexandria, Egypt.

[7] http://en.wikipedia.org/wiki/Abu_Qir.

[8] Frank Goddio Society homepage; online: http://www.franckgoddio.org/

[9] Ferro, L., Alexandria beyond the myth, Architecture Archeology urban change, edited by Luisa Ferro and Cristina Pallini, ArabAFenice: 2009.

[10] Azam, Y.; Alexandria University, Studying urban and regional planning of Abuqir, Egyptian committee for Industry and Environment, 2004.

[11] Orbasli, A.; "Architectural conservation: principles and practice"; Blackwell publishing, 221p. , 2008.

[12] Gallo, P., Nelson's Island 2002, Preliminary report on the excavation of British military personnel c17981801, 19 October to 29 November 2002, online. http://www.nelson-society.com/html/documents/NelsonIsland Reports.pdf

[13] Morcos S, Tongring N, Halim Y, El-Abbadi M, Awad H. "Towards integrated management of Alexandria's coastal heritage" UNESCO 2003. Paris, France, (2003).

[14] El-Raey, M., Nasr, S., Frihy, O., Fouda, Y., El-Hattab, M., Elbadawy, O. and Mohammed, W., Sustainable Development of The Coastal Area of Abu-qir bay, Egypt, 1st Inter. Conf. on Envir. Change of Lakes, Lagoons and Wetlands of the Southern Mediterranean Region, 3-7 January, 06, Cairo, Egypt. ECOLLAW, (CEDARE), 2006.

[15] Yasser, G. A., “Alexandria's Forgotten Architecture, Defensive Buildings of Alexandria", First Euro Mediterranean Regional Conference, Traditional Mediterranean Architecture. Present and Future, RehabiMed, Barcelona, Spain, July 2007. (poster session).

[16] Sap H., M.Sc., "Corridors and/or linear cities; a historic contribution to contemporary discussion on corridor development", Eindhoven University of Technology, Faculty of Building and Architecture, Urban Design Group, 2002. 